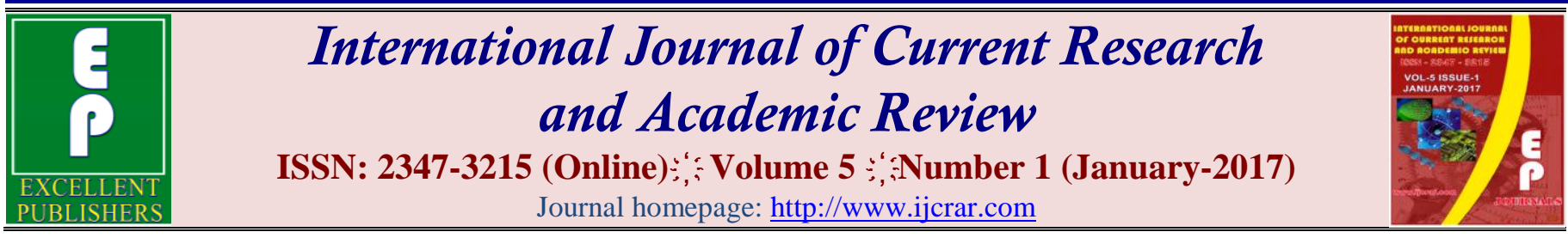

doi: http://dx.doi.org/10.20546/ijcrar.2017.501.014

\title{
Workplace Environment and Employee Performance in Selected Brewing Firms in Anambra State
}

\author{
Hope Ngozi Nzewi*, Obianuju Mary Chiekezie and Chibuzoh Alphonsus
}

Faculty of Management Sciences, Nnamdi Azikiwe University, Awka, Nigeria

*Corresponding author.

\begin{abstract}
The potentials inherent in most brewing firms in Nigeria appeared thwarted by the physical workplace environment in the industry. The broad objective of this study was to determine the relationship between workplace environment and performance of employees in the selected brewing firms in Anambra state, while the study specifically ascertained the type of relationship existing between physical workplace environment and employee commitment. The study was anchored on Dawes and Lofquist (1984) Theory of Work Adjustment (TWA). The study employed Correlation Survey Research Design. Data for the study were collected through primary source and analyzed using Pearson's Product Moment Correlation on SPSS version 22. The findings revealed that there was high positive significant relationship between physical workplace environment and employee commitment. It was recommended that Management of organizations should place more importance to employee health and safety by providing necessary facilities, conducive work environment and take actions for employee welfare towards accomplishing set objectives that drive the firms to peak performance.
\end{abstract}

\section{Article Info}

Accepted: 10 January 2017

Available Online: 20 January 2017

\section{Keywords}

Workplace Environment, Physical Workplace Environment, Employee Performance and Employee Commitment.

\section{Introduction}

The environment is man's immediate surrounding which he manipulates for his existence. Wrongful manipulation introduces hazards that makes the environment unsafe and impede employee's performance. The workplace entails an environment in which the employee performs his work (Chapins, 1995) while an effective workplace is an environment where results can be achieved as expected by management (Mike, 2010; Shikdar, 2002). Physical environment affect how employees in an organization interact, perform tasks, and are led. Physical environment as an aspect of the work environment has directly affected the human sense and subtly changed interpersonal interactions and thus employees' commitment (Ajala, 2012). This is so because the characteristics of a room or a place of meeting for a group have consequences regarding employee's commitment and satisfaction level. The workplace environment is the most critical factor in keeping an employee committed in today's business world. Today's workplace is different, diverse, and constantly changing. The typical employer/employee relationship of old has been turned upside down. Workers are living in a growing economy and have almost limitless job opportunities. This combination of factors has created an environment where the business needs its employees more than the employees need the business (Smith, 2011). 
Every organization wants to have employees with the necessary skills for achieving its organizational needs, employees who are committed to organization and have high performance. Therefore any organization competing for the best employees, need to do something to attract potential employees. One of the things that can be done to attract potential employees is to establish a pleasant working environment. According to Jain and Kaur (2014) Workplace environment involves all the aspects which act and react on the body and mind of an employee. A congenial work environment minimizes fatigue, monotony and boredom as well as maximizes work performance. Workplace environment is one of the comprehensive concepts because it includes aspects of physical, psychological and social working conditions. The work environment can have a positive and negative effect on the psychology and welfare of employees.

The brewing firms of focus are Nigerian breweries Plc and SABMiller plc. Each of these firms seeks many experienced and qualified employees from rival firms, with an offer of a better salary and compensation package. Although compensation package is one of the extrinsic motivation tool (Ryan \& Deci, 2000) it has a limited short term effect on employees' commitment. A widely accepted assumption is that better workplace environment motivates employees and produces better results. Gyekye (2006) indicates that environmental conditions affect employee safety perceptions which impact upon employee commitment. An improved working environment may results in a reduction in the number of complaints and absenteeism and an increase in productivity. The indoor environment has the biggest effect on employee performance in relation to job stress and job dissatisfaction. As suggested by Govindarajulu (2004), in the twenty-first century, businesses are taking a more strategic approach to environmental management to enhance their performance through improving the performance level of the employees. It is against this backdrop that a study of this kind is imperative in the selected brewing firms in Anambra state, south-east of Nigeria.

\section{Statement of the problem}

Despite the immense contribution of brewing firms to the growth of Nigerian economy, the potentials inherent in this industry appear thwarted by the physical workplace environment in the industry. Brewing firms depend heavily on the performance of their employees; the performance of employees also depends heavily on the workplace environmental factors. One of which is physical workplace environment. This factor seems to influence the employees' performance and the commitment towards the goals, objectives, mission and vision of the organization.

It was observed from Nigerian breweries Plc and SABMiller plc - the focused organizations- that the workplace environment in most Nigerian brewing firms is unsafe and unhealthy, probably due to the state of infrastructures, number of obsolete machines, poorly designed workstations, lack of proper ventilation, inappropriate lighting, excessive noise, insufficient safety measures in fire emergencies and lack of personal protective equipment. People working in such environment are prone to occupational disease and it could have effect on employee's performance. Thus, the employee's commitment to the organization tends to decrease due to the nature of the physical workplace environment.

However, the employees of these firms have been observed to exhibit nonchalant attitudes to work. Laxity, mediocrity, and ineptitude currently reign among them while their work philosophy has become that of 'service to self' rather than 'service to the firm. Hardly would anyone find any employee of this firm who is not job hunting. This is a clear indication that commitment among these employees may be affected. The problem becomes more worrisome because lack of commitment may contribute to the fall in performance of these firms. It may also be responsible for the drastic fall in the number of brewing firms from 36 operational brewing firms in 1983 to 14 operational brewing firms in Nigeria today (Olu, 2015). The relationship between physical workplace environment variables and commitment may affect employee performance at workplace. Therefore, based on this problem, a study needs to be done to ascertain the type of relationship exiting between the physical work environment and employee commitment in the organisation.

\section{Objective of the study}

The broad objective of the study is to determine the relationship between workplace environment and performance of employees in the selected Brewing Firms in Anambra State. The specific objective is to:

Ascertain the nature of relationship that exists between physical workplace environment and employee commitment in selected Brewing Firms in Anambra State. 


\section{Research Question}

To achieve the objective, the following research question is formulated:

What is the nature of relationship that exists between physical workplace environment and employee commitment in selected Brewing Firms in Anambra State?

\section{Hypothesis}

$\mathrm{H}_{\mathrm{A}} \quad$ There is significant relationship that exists between physical workplace environment and employee commitment in selected Brewing

Firms in Anambra State.

\section{Review of Related Literature}

\section{Conceptual Review}

\section{Workplace environment}

Many scholars have attempted conceptualizing the workplace environment. It can be defined in its simplest form as the settings, situations, conditions and circumstances under which people work. It is further elaborated by Briner (2000), as a very broad category that encompasses the physical setting (e.g. heat, noise, equipment etc.), characteristics of the job itself (e.g. workload, task complexity), broader organizational features (e.g. culture, history) and even aspects of the extra organizational setting (e.g. local labour market conditions, industry sector, work-home relationships). It means that workplace environment is the sum of the interrelationship that exists among the employees and the employers and the environment in which the employees work which includes the physical/technical, the human and the organizational environment.

Opperman, (2002) as quoted in Yusuf and Metiboba, (2012), defined workplace environment as the composition of three major sub-environments which include the physical/technical environment, the human environment and the organizational environment. According to them physical workplace environment refers to tools, equipment, technological infrastructure and other physical or technical elements of the workplace. The human environment includes the peers, others with whom employees relate, team and work groups, interactional issues, the leadership and management. The human environment can be interpreted as the network of formal and informal interaction among colleagues; teams as well as boss-subordinate relationship that exist within the framework of organizations. Such interaction (especially the informal interaction), presumably, provides avenue for dissemination of information and knowledge as well as cross-fertilization of ideas among employees. The third type of workplace environment is organizational environment. Organizational environment refers to the immediate task and national environment where an organization draws its inputs, processes it and returns the outputs in form of products or services for public consumption. The task and national environment includes factors such as supplier's influence, the customer's role, the stakeholders, sociocultural factors, the national economy, technology, legislations, managerial policies and philosophies (Akintayo, 2012).

\section{Physical workplace environment}

A physical work environment can cause a person to fit or misfit in the environment of the workplace. A physical work environment can also be known as an ergonomic workplace.

According to Stup (2003), physical workplace environment is the environment where human beings are fit with their job. This physical work environment might include the light, ventilation and also temperature.

Amir (2010), asserts that, a physical workplace is an area in an organization that is being arranged so that the goal of the company could be achieved. The two main elements in the physical workplace environment are the office layout plan and the office comfort.

Statt (1994) opines that the modern work physical environment is characterized by technology; computers and machines as well as general furniture and furnishings. To achieve high levels of employee performance, organizations must ensure that the physical environment is conducive to organizational needs facilitating interaction and privacy, formality and informality, functionality and cross-disciplinarily. Consequently, the physical environment is a tool that can be leveraged both to improve business results (Mohr, 1996) and employee well-being (Huang, Robertson and Chang, 2004).

\section{Employee performance}

The most important dependent variable is the employees' performance (Borman, 2004). According to Sinha 
(2001), employees' performance is dependent on the willingness and the openness of the employees in doing their job. Further he stated that by having this willingness and openness of the employees in doing their job, it could increase the employees' productivity which also leads to the performance.

An employee's performance can also be determined as a person's ability to perform also including the opportunity and willingness to perform as well. The meaning of willingness to perform means that the desire of the employees in putting as much effort towards their job (Eysenck, 1998).

\section{Employee commitment}

Dixit and Bhati (2012), revealed that the concept of organizational commitment was derived from Whyte's article in 1956, The Organization Man, which states that commitment comes into being when a person links extraneous interests with a consistent line of activity by making a side bet. In this review, organisational commitment is used synonymously with job commitment both of which entails more psychological concepts than environmental factors of workplace. Yusuf and Metiboba (2012), submit that job commitment is psychological states that characterizes the employee's relationships with the organisation; and has implications for the decision to continue discontinue membership in the organisation. Job commitment therefore entails attitude or orientation towards the organization which links or attaches the individual or worker to the establishment. It is a process whereby the goals of the individual or worker are increasingly integrated with that of the organization. Job commitment entails three components which include: workers' readiness to exert effort on behalf of the organization; workers' acceptance of organizational goals and values; and workers desires to remain with the organization (Ogaboh, Nkpoyen \& Ushie, 2010). The concept of job commitment would not be sufficiently meaningful without defining it in the manner that Meyer and Allen did. Job commitment according to them is defined as the force that binds an individual to a course of action relevant to one or more targets on the job. Employees are therefore believed to experience this commitment in three bases, or mind-sets that play a role in shaping behaviour: affective, normative, and continuance, (Meyer \& Herscovitch, 2001; Jaros, 2007; McMahon, 2007; Sundas, Noor \& Shamim, 2009; Ogaboh et al., 2010; Yusuf \& Metiboba, 2012).

Fig.1 Conceptual Framework of workplace environment and Employee Performance

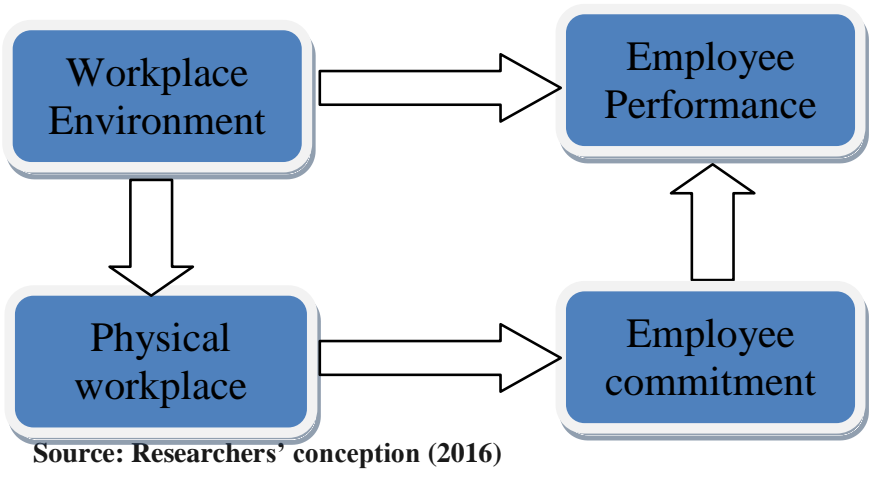

In simple terms, these three dimensions of job commitment imply emotional ties (affective) perceived sunk costs in relation to a target (continuance) and perceived obligation (normative). With affective commitment, employees are committed to the job because they "want to". With continuance commitment employees are committed to the job because they "have to". With normative commitment, they are committed because they "ought to" These three types of commitments begs for application, and empirical testing among staff of Nigerian Breweries plc and SABMiller plc.

From figure 1, workplace environment is seen to be the determinant of employee performance, physical workplace environment seen immediately below workplace environment is one of workplace environment factors that determine employee commitment in an organization.

\section{Theoretical framework}


This study is anchored on Theory of Work Adjustment (TWA) developed by Dawes and Lofquist in the University of Minnesota, 1984. The theory describes the relationship that exists among individuals at work and their work environment. Work is therefore perceived and conceptualized as an interaction between an individual and a work environment. This work environment requires that certain tasks are performed, and the individual brings up the needed skills to perform the tasks. As an exchange relationship (between the individual and the workplace environment), the individual also requires certain compensation or rewards for work performance and certain preferred conditions, such as a safe and comfortable place to work. For the interaction to be maintained and job to continue, the workplace environment and the individual must continue to meet each other's requirements (Dawes \& Lofquist, 1984). The degree to which the requirements of both are met is called correspondence. This is why TWA is also known as Person-Environment Correspondence Theory.

The forgoing has implication for this study. Where employees perceive some factors in the physical workplace environment as unconducive, then such environment may be construed as being unhealthy and unsafe. Hence, for an environment to be perceived as conducive, the Person-Environment relationship must be corresponding (i.e. the requirement of person and environment must be met). Where there is a lack of correspondence means that commitment may be affected. These further shows the need for empirical probing into the various gaps identified in this review.

\section{Empirical review}

Ajala (2012) conducted a survey research design of the expose facto type to investigate the influence of workplace environment (workspace and communication) on workers welfare, performance and productivity in Ondo state. The populations for the study are employees of government parastatals in Ondo State. Three parastatals were randomly selected. They are, Ondo State Electricity Board, Ondo State Waste Disposal Board and Ondo State Hospitals Management Board. A total of one hundred and twenty respondents (management, middle and junior cadres) were randomly selected from each establishment to give a total of three hundred and fifty respondents. Data collected were analyzed with mean values and simple percentages. The results showed that workplace features and good communication network at workplace have effect on worker's welfare, health, morale, efficiency, and productivity.

Chandrasekar (2011), conducted a descriptive research of both primary data and secondary data on workplace environment and its impact on Organizational performance in public sector Organizations using the stratified random sampling method. The total population divided into groups and the samples are collected randomly from these groups. By adopting proportional allocation among three departments, viz., engineering building, Administration building and Shop floor building, among 285 employees. Data collected was analyzed with simple percentages. His findings revealed that there is a positive relationship between work, the workplace and the tools of workplace becomes an integral part of work itself.

Asigele (2012), carry out a cross sectional exploratory study on the effect of working environment on workers performance: the case of reproductive and child health care providers in tarime district.12 health facilities in the tarime district. One hospital, three health centres and eight dispensaries were involved in the study. Data was collected using closed and open ended questionnaires. The main variables in the questionnaire were sociodemographic characteristics (sex, age, and marital status and education level), availability of drugs, office building space, presence of privacy, availability of medical supplies. 30 health providers and 147 clients were interviewed. Data collected were analyzed with the aid of SPSS version 15.0 whereby frequency tables were run and mean and standard deviation were calculated afterword correlation and regression analysis conducted. The result reveals that the working environment elements have a significant effect on the performance of health providers in the Reproductive and Child Health unit

Nina and Mohammad (2013) carried out a survey study on Factors of Workplace Environment that Affect Employees Performance: A Case Study of Miyazu Malaysia. The study was aimed to investigate the effect of workplace environment's factors towards employees' performance. Data was collected from a total of 139 employees who participated from three main workplace of Miyazu (M) Sdn. Bhd. Data collected were analyzed using correlation and regression analysis on SPSS ver. 20.Based on the findings it shows that only supervisor support is not significant towards the employees' performance. Meanwhile, job aid and physical 
workplace environment are having a significant relationship towards the employees' performance.

Demet (2012), conducted a survey study on the impact of workplace quality on employee's productivity: a case study of a bank in Turkey. The research investigated dimensions of workplace environment in terms of physical as well as behavioral components. The analysis was implemented to a private foreign bank in Turkey which has 300 employees. In the study both primary and secondary data was used. The data collected were analyzed uses mean and percentages. The survey was employed to the call center personnel of the bank who mostly are affected from the workplace conditions than the other employees due to their job requirements. The result reveals that workplace environment affects employee performance but behavioral workplace environment has greater effect on employees' performance. Hence he concludes that there is a significant positive relationship between workplace quality and productivity among bank workers.

Junaida et al., (2010), investigated the physical work environment on staff productivity. With 150 participants among civil servants in the Ministry of Youth and Sports in Malaysia, the study revealed that working conditions was significantly related to employee productivities. This was however on workplace environment and employee productivity.

Thushel (2015), conducted a cross-sectional study on the relationship between work environmental factors and job performance with work motivation and the extent to which this relationship was mediated by work motivation among a sample of hotel workers in England. In this cross-sectional study, a questionnaire survey was conducted among 254 hotel workers at twenty-five chain hotels in Bristol, England. The results suggest that there is a significant relationship between work environmental factors and job knowledge, physical ability to carry duties, communication skills, teamwork skills, punctuality and concentration to duties all of which were used to measure job performance and that work motivation mediates the relationship between working conditions and job performance. The results also suggest that there is a significant relationship between work motivation and job performance of the hotel workers. The results point to the importance of working conditions and work motivation in explaining job performance of hotel workers in the framework of work environmental conditions and job performance.

Parthasarathy (2015), conducted a survey study on the Role of physical work environment on organizational performance a study of Mysore Milk Union Ltd, Mysore. 50 respondents working at Mysore Milk Union Ltd, Mysore are taken as the sample. The questions relating to physical work environment comprises of three parameters namely facilities provided, space configuration, and medical facilities. The question relating to organizational performance comprises of two parameters namely leadership styles and absenteeism.

Correlation and chi - square test were used to analyze the data. The results indicate that there exist a positive relationship between physical work environment and organizational performance. Hence he concludes that physical work environment can be employed for assessing organizational performance.

\section{Research methods}

\section{Research design}

The study employed Correlation Survey Research Design

\section{Population of the study}

\begin{tabular}{llr}
\hline Brewing Firms & Locations & Population \\
SABMiller plc & Harbor industrial layout Onitsha, Anambra State & 488 \\
Nigerian Breweries Plc & 87/97 Portharcourt Road, Onitsha, Anambra State & 60 \\
Total Population & & 548 \\
\hline
\end{tabular}

Source: Field Survey, 2016.

Table 3.1 shows the population of the study. the population of the study at the time of survey consists of 548 employees drawn from the two existing brewing firm in Anambra state which are: Nigerian Breweries plc, Onitsha (60) and SABMiller plc, Onitsha (488)

\section{Sample Size and Sampling Technique}

Krejcie and Morgan (1970) formula was used to determine the sample size that will be the true representation of the entire population of the study. 
As shown below.

$s=\frac{X^{2} N P(1-P)}{d^{2}(N-1)+X^{2} P(1-P)}$

Where

$\mathrm{S}=$ Sample size

$\mathrm{X}^{2}=$ Table value of chi-square for 1 degree of freedom @ $0.05 \%$ confidence level (3.84)

$\mathrm{N}=$ population size $(548)$

$\mathrm{P}=$ population proportion (assumed to be 0.5 since this would provide the maximum sample size)

$\mathrm{d}=$ Degree of accuracy express as a proportion $(0.05)$

$S=\frac{3.84(548)(0.5)(1-0.5)}{(0.05)^{2}(548-1)+(3.84)(0.5)(1-0.5)}$

$S=\frac{526.08}{1.3675+0.96}$

$S=\frac{526.08}{2.3275}$

$\mathrm{S} \cong 226$

\section{Instrument for Data Collection}

Data were collected from primary source. The primary data were gathered from respondents through questionnaire instrument structured in a 5 point likert scale. Bowley's proportionate allocation formula was

\section{Questionnaire Distribution and Retrieval Table}

further used to determine the number of questionnaires to be distributed to each of the brewing firm.

SABMiller plc $=\frac{488 \times 226}{548}=201$

Nigerian Breweries $=\frac{60 \mathrm{X} 226}{548}=25$

\begin{tabular}{lllll}
\hline S/N & Brewing Firms & Distributed & Retrieved & Not retrieved \\
$\mathbf{1}$ & SABMiller plc & 201 & 128 & 28 \\
$\mathbf{2}$ & Nigerian Breweries Plc & 25 & 21 & 4 \\
& Total & $226(100 \%)$ & $194(86 \%)$ & $32(14 \%)$ \\
\hline
\end{tabular}

Source: Field Survey, 2016.

\section{Validity of Instrument}

The instrument for data collection was subjected to content validity and face validity by the researchers and some research experts to ensure that the items of the questionnaire capture the variables of the study.

\section{Reliability of Instrument}

The reliability of items used in the research instrument was measured by using the Cronbach's alpha test. In order for measurements to be acceptable, the minimum acceptable level of the Cronbach's alpha score should be equal to or more than 0.70 (alpha $\geq 0.70$ ), as suggested by Sekaran (2003). The Cronbach's alpha score for the item is 0.877 indicating an excellent internal consistence.

\section{Reliability Statistics}

\begin{tabular}{|l|l|}
\hline Cronbach's Alpha & N of Items \\
\hline .877 & 10 \\
\hline
\end{tabular}

Source: Field survey, 2016 


\section{Computation: SPSS ver. 22}

\section{Method of Data Analysis}

Pearson's Product Moment Correlation Coefficient on SPSS ver. 22 was used to

\section{Test of Hypothesis}

\section{Hypothesis Test Table}

Correlations

\begin{tabular}{|ll|l|l|}
\hline & & $\begin{array}{l}\text { Physical Workplace } \\
\text { Environment }\end{array}$ & $\begin{array}{l}\text { Employee } \\
\text { Commitment }\end{array}$ \\
\hline Physical & Pearson Correlation & 1 & $.917^{* *}$ \\
Workplace & Sig. (2-tailed) & & .000 \\
Environment & $\mathrm{N}$ & 194 & 194 \\
\hline Employee & Pearson Correlation & $.917^{* *}$ & 1 \\
Commitment & Sig. (2-tailed) & .000 & 194 \\
& $\mathrm{~N}$ & 194 & \\
\hline
\end{tabular}

**. Correlation is significant at the 0.01 level (2-tailed).

Source: Field Survey, 2016

SPSS Ver. 22 determine the type of relationship that exists between the dependent variable and independent variable. The level of significance used was $5 \%$ and the confidence interval of $95 \%$

\section{Summary of findings, conclusion and recommendations}

\section{Summary of findings}

From the hypothesis test table, table 4.1, physical workplace environment was shown to have a significant positive relationship with employee commitment with the correlation coefficient of 0.917 which is very high and probability value of 0.000 (p-value $<0.01$ ) which is less than the significant level at 0.01, 2-tailed test. Based on this result, the research hypothesis which states that, there is a positive significant correlation between physical workplace environment and employee commitment in selected Brewing firms in Anambra State is therefore accepted.

\section{Discussion of Findings}

The findings of this study revealed that there exist a strong positive correlation between physical workplace environment and employee commitment. The implication of this is that, any improvement in the physical workplace environment of the organization will lead to improvement in employee commitment. That is, as management improves the conditions of office environment, workplace designs, noise free environment communication network, the employee will have the feeling that the organization is not only concern over profit making but also on the health and safety of its employee and this will increase employee commitment, eventually improve employee performance and ultimately organizational performance. This result is consistent with the previous findings of Ajala (2012) which stated that workplace features and good communication network at workplace have effect on worker's welfare, health, morale, efficiency, and productivity. Similarly, Asigele (2012), found that, the working environment elements have a significant effect on the performance of health providers in the Reproductive and Child Health unit.

\section{Conclusion}

The researcher concludes that, workplace environment play pertinent role in improving employee performance in organizations. Since money is a short term motivator in encouraging employee commitment required in today's competitive business environment.

\section{Recommendations}

Based on the findings, the following recommendations are made: 
1.Management of organizations should place more importance to employee health and safety by providing necessary facilities conducive work environment, and take actions for employee welfare this will encourages employees' commitment and create personal goals that align with organizational goals thus drive the organization to peak performance.

2.Managers and supervisors of organizations should periodically evaluate the work environment which includes the physical work environment. In order to prevents decrease employee commitment.

\section{Contribution to Knowledge}

This study contributes a conceptual framework that links physical workplace environment to employee commitment and also provide empirical result on the linkage and type of relationship existing between the constructs in the selected brewing firms in Anambra State.

\section{References}

Abdullah, Ramay, Muhammad \& Ismail. 2012. Antecedents of Organizational Commitment of Banking Sector Employees in Pakistan. Serbian J. Management, 7(1): 89-102.

Ajala, E.M. 2012. The influence of workplace environment on workers' welfare, performance and productivity. The African Symposium: An online J. African Educational Res. Network, 12(3): 141-149

Akintayo, D. 2012. Working environment, workers' morale and perceived productivity in industrial organizations in Nigeria. Education Res. J., 2(3): 87-93.

Amir, F. 2010. Measuring the impact of office environment on performance level of employees: A case of private sector of Pakistan. Proceedings of the 2nd Int. Conference of AGBA South Asia Chapter on Nurturing Innovation, Entrepreneurship, Investments and Public Private Partnership - in Global Environment. Bhurban, Pakistan

Asigele, O. 2012. The effect of working environment on workers performance: the case of reproductive and child health care providers in tarime district. Muhimbili University of Health and Allied Sciences November, 2012

Bakotic, Danica, Babic, Tomislav. 2013. Relationship between Working Conditions and Job
Satisfaction: The Case of Croatian Shipbuilding Company. Int. J. Business and Social Sci., 4(2), 206-213.

Briner, R.B. 2000. Relationships between work environments, psychological environments and psychological well-being: in-depth review. Occup. Med., 50(5), 299-303.

Brill, M. 1992. How design affects productivity in settings where office-like work is done. $J$,

Health Care Design, 4, 11-16.

Borman, W.C. 2004. The concept of organizational citizenship. Curr. Directions in Psychol. Sci., 13(6), 238-241.

Chandrasekar, K. 2011. Workplace environment and its impact on Organisational performance in public sector Organisations. Int. J. Enterprise Computing and Business Systems, (1) 1-20.

Chapins, A. 1995. Workplace and the performance of workers, Reston: USA.

Cooper, C., Dewe, P. 2004. Stress, a brief history. Oxford: Blackwell Publishing.

Danish, R.Q., Ramzan, S \& Ahmad, F. 2013. Effect of Perceived Orgamizational Support and Work Environtment on Organizational Commitment; Mediating Role of Self-Monitoring. $A d v$. Economic and Business, 1(4), 312-317

Dawes, R.V. \& Lofquist, L.H. 1984. Apsychological theory of work adjustment. Minneapolis: University of Minnesota Press.

Demet, L. 2012. Impact of workplace quality on employee's productivity: case study of a bank in Turkey. J. Business, Economics \& Finance, $1(1)$.

Dixit, V. \& Bhati, M. 2012. A study about employee commitment and its impact on sustained productivity in Indian Auto-Component Industry. European J. Business and Social Sci., 1(6), $34-51$.

Eysenck, M. 1998. Psychology: An integrated approach. New York: Addison - Wesley Longman Ltd.

Furnivall, L. 2009. The Perfect Storm: A Review of the Influence of Guinness Breweries PC in Africa. New York: W.W. Norton Co

Hameed, A. \& Amjad, S. 2009. Impact of office design on employees' productivity: A case study of banking organisations of Abbotttabad, Pakistan. $J$. Public Affairs, Administration and Management, 3(1).

Jain, R. \& Kaur, S. 2014. Impact of Work Environment on Job Satisfaction. Int. J. Scientific and Res. Publications, 4(1), 1-8. 
Jaros, S. 2007. Meyer and Allen model of organizational commitment: Measurement Issues, The Icfai University Press.

McCoy, J.M., \& Evans, G.W. 2005. Physical work environment. In: J. Barling, E. K. Kelloway\& M. R.Frone (Eds. Handbook of Work Stress. Thousand Oaks, CA: Sage Publication pp. 219245.

McMahon, B. 2007. Organizational commitment, relationship commitment and their association with attachment style and locus of control. M. Phil. Thesis of the School of Psychology, Georgia Institute of Technology.

Meyer, J.P. \& Herscovitch, L. 2001. Commitment in the workplace: toward a general model. Human Resource Management Review, 11(2), 299-326

Mike, A. 2010. Visual workplace: How you see performance in the planet and in the office. Int. J. Financial Trade, 11(3), 250-260.

Nina, M.N. \& Mohammad, S. 2013. Factors of Workplace Environment that Affect Employees Performance: A Case Study of Miyazu Malaysia. Int. J. Independent Res. Studies - IJIRS. Vol. 2, No.2 (April, 2013) 66-78.

Ogaboh, A.A.M., Nkpoyen F., \& Ushie, E.M. 2010. Career development and employee commitment in industrial organisations in Calabar, Nigeria: American J. Scientific and Industrial Res., 1(2).

Ola, B. 2001. The Brewer's Story.Financial Standard. Lagos. November.

Olukunle, S.O. 2015. Workplace Factors As Determinants Of Job Commitment Among Senior Non-Teaching Staff Of Olabisi Onabanjo University, Ogun State.

\section{How to cite this article:}

Hope Ngozi Nzewi, Obianuju Mary Chiekezie, Chibuzoh Alphonsus. 2017. Workplace Environment and Employee Performance in Selected Brewing Firms in Anambra State. Int.J.Curr.Res.Aca.Rev. 5(1), 111-120.

doi: http://dx.doi.org/10.20546/ijcrar.2017.501.014
Parthasarathy, N. 2015. The Role of physical work environment on organizational performance: A case study of Mysore Milk Union Ltd, Mysore. Int. J. Adv. Res. Computer Sci. Management Studies, 3(2).

Sekaran, U. 2007. Research methodology for business: A skill building approach, (4th ed.), New Delhi: John Wikey \& Sons.

Shikdar, A.A. 2002. Identification of ergonomic issues that affect workers in oilrigs in desert environment. Int. J. Occupational Safety and Ergonomic, 10(8), 169- 177.

Sinha, E.S. 2001. The skills and career path of an effective project manager. Int. J. Project Management, 19, 1-7.

Smith, D.G. 2011. Work environment more important to employees. Retrieved May 25, 2016 from http://www.businessknowhow.com.

Sundas, W., Noor F., \& Shamim. A.S. 2009. Study on relationship between organizational commitment and its determinants among private sector employees of Pakistan. Int. Review of Business Res. Papers, 5(3), 399- 410

The Gensler Design + Performance Index, The U.S. Workplace Survey, 2006. www.gensler.com

Thushel, J. 2015. Impact of work environmental factors on job performance, mediating role of work motivation: a study of Hotel sector in England. Int. J. Business and Management, 10(3).

Uludag, Orhan, Khan, Sonia, Guden \& Nafiya. 2011. The Effects of Job Satisfaction, Organizational Commitment, Organizational Citizenship Behavior on Turnover Intentions. Florida International University Review, 29(2): 1-21. 